New Form of Heliostat. C. F. Chandler-A New Polariscopic Method for the Detection and Estimation of Dextro-glucose in the Presence of Cane'Sugar and Inverted Sugar. A. Graham BellVowel Theories considered in the Light of Recent Experiments with the Phonograph and the Phonautograph. Elias LoomisThe Winds on Mount Washington Compared with the Winds near the Level of the Sea. Henry L. Abbot-The Ignition of High Tension Fuses. Alexander Agassiz-Report on Dredgings in the Caribbean Sea by the Coast Survey Steamer Blake, Commander, John R. Bartlett, U.S.N. C. F. Chandler-On Two New Diazo Colours from Coal Tar. G. J. Brush-On a Mineral Locality in Fairfield County, Connecticut. H. A. Newton-On the Influence of Jupiter on Bodies passing near the Planet. J. S. Newberry-On the Great Silver Deposit recently Discovered in Colorado, Utah, and Nevada. Simon Newcomb -On the Recurrence of Solar Eclipses, F. A. P. BarnardReport of the Committee on Weights, Measures, and Coinage.

\section{NATIONAL WATER SUPPLY}

7 HE Society of Arts has again done useful work in bringing together a jury of experts on the question of water supply; for though the subject has engaged public attention for nearly half a century, has been investigated by Royal Commissions, and inquired into by committees appointed by scientific societies, we still find ourselves face to face with so costly and cumbersome a system of legislature, that although the country receives a rainfall which has been amply demonstrated to be far in excess of all the requirements of human consumption, manufacturing interests and purposes of canalisation, we see large districts suffering all the ills due to a polluted water-supply, whilst in other areas excessive rainfall is passing to the sea in devastating floods.

It is obvious, from a consideration of this fact, that there exists but one remedy for this state of things-the creation of a central authority, with power over the whole waterrights of the country for all purposes whatsoever; and upon this point there is a most striking unanimity of opinion in all the speakers attending the Society of Arts conference this year and last. Whether this authority should be placed over the whole of the 215 river basins of England and Wales, or whether they should be subdivided into groups, each presided over by separate bodies, is a question of detail, and it is necessarily one which allows of a very large amount of difference of opinion, varying with the special knowledge and tendencies of the individual propounding the scheme.

Sir Henry Cole last year suggested a division into seven districts, each under a local commission, assisted by a well-known engineer, together forming a united board, for the discussion of general questions.

Mr. Shelford pointed out that 158 river basins are contained in one county, and might be presided over by county boards, while only eleven rivers are situated in four or more counties, for which he considers special legislation would be necessary. Mr. De Rance would divide the country into six groups of river basins, Mr. Conder into ten, and he suggested the formation of a board similar to the Hydraulic Works Department in Italy, who at once take charge of the area and population of each province, the altitude of the ground, the volume of the rivers, and the amount of rainfall.

To elicit information as to the best means of dividing the country into separate watershed areas, having regard to the wants of the population and the geological and hydrological conditions, the Society of Arts offered for competition, at the Congress just held, a gold and three silver medals. No paper, it appears, has been judged of suffcient value to entitle the author to the gold medal, but two, of the seven papers selected for printing, have been thought worthy of silver medals, contributed by Mr. F. Toplis and Mr. J. Lucas. The former proposes that the country should be mapped out into watershed districts of one or more river basins, governed individually by a body of commissioners, assisted by competent legal and engineering advisers, with charge over all rivers, and power to acquire all existing water-works and canals, acting under the direction of a Minister of Health.

Mr. Lucas divides the country into northern, midland, and southern districts, with the idea of giving the commissioner presiding over each area a similar disposition of mountains and plains and constituent geological strata.

Other authorities propose still other subdivisions, and we cannot but think that the legislative creation of a numerous body of commissioners, in various districts, each with varying requirements and conflicting vested interests, would for the present only tend to increase the existing confusion; for, as we stated last year, quoting Dr. Child, "the bane of all local government in England is the chaos of different and often conflicting authorities, existing each for a special purpose." It is difficult to see how this state of things would be improved by the large powers proposed to $b_{2}$ given to a number of new local governing bodies. For ourselves we are more inclined to agree with Capt. Douglas Galton, that all existing information should be brought to one focus, and though this information lies scattered over many departments, the Local Government Board is the legitimate focus for it ; and that whether or no it is considered necessary that a Minister of Health be appointed, the preliminary step which can at once be taken is to place the heads of departments who hold information in official relation with the Local Government Board. The departments he specially referred to, being the Geological Survey, the Ordnance Survey, the Register-General's Department, and the Rainfall Committee.

The maps of the Ordnance Survey that would be most useful for hydrological purposes are those on the scale of six inches to the mile, published for the six northern counties, part of Flintshire, and for the neighbourhood of London; but unfortunately for those who have recognised the practical value of the maps on this scale, for economic purposes, the Directors of the Ordnance Survey have given priority of appearance to the larger 25-inch maps, which in addition to the objection found to their use, from the small area they include, do not contain the contour lines of equal level, which give to every 6-inch map the usefulness of a model. The Ordnance Survey are, however, bringing out a new issue, brought up to date, of their I-inch map of England and Wales, reduced from their 25 -inch map; this new $\mathrm{I}$-inch map has no hill-shading, which so often obscured the topography of the older editions, but in its place contains the principal contour lines. This map will form an admirable basis for tracing the watersheds and other hydrological purposes for which the published Ordnance Survey Catchment Basin Map is far too small.

The information collected by the Geological Survey, consists of geological maps of a large region on the scale of one inch to the mile, and of maps on the six-inch scale in the northern counties, coloured for the geological formation, and "stippled" for the superficial clays and sands with which they may be overlaid; sections across country on the six-inch scale, showing the thickness of the various permeable and impermeable formations; memoirs descriptive of districts, and including the more minute details of the strata, and particulars of the wellsections. On the latter head we would specially allude to the exhaustive detail of wells, given in the memoir of the London basin, by Mr. Whittaker, which has furnished so practical a basis for the useful investigations of $\mathrm{Mr}$. Lucas, who has added to them, from personal examination, the level of the underground water in the metropolitan area.

From information supplied by $\mathrm{Mr}$. De Rance to the conference, it appears that the pervious water-bearing formations occupy about 22,000 square miles, absorbing on an 
average about ten inches of rainfall a year, which, if all yielded up to wells, would give a daily average supply of 400,000 gallons per square mile, and he further shows that the larger area of these permeable formations lies east of the great water-shed, dividing England diagonally, and separating the Severn and Trent basins on the one side, from those of the Thames, east coast streams, Witham and Ouse on the other, the only important previous formation west of this boundary being the permian and new red sandstones. The latter occupies an area of 3 , 190 square miles.

This different disposition of the permeable and impermeable strata in England, at once explains how it is that the dry-weather flow of rivers like the Thames, draining a basin largely consisting of permeable strata, differs so remarkably in volume from rivers like the Severn, mainly occupied by impermeable silurian rocks and triassic marls, and the necessity is at once apparent of there being a central authority, taking cognisance of all matters bearing on water questions, and assisting parliament in giving or withbolding to any corporation or district the water rights of any area to which they may lay claim. Thus, in the case of Liverpool, it is proposed to take from the sources of the Severn, a quantity of not less than 52,000,000 gallons a day, while Mr. Hawksley, in evidence before the Royal Rivers Commission, gives the driest weather flow, so low down the Severn as Tewkesbury, as only $90,000,000$ gallons per day. With a margin so small, it is obvious that the maintaining of a sufficient volume of water for navigation, fisheries, and other purposes, is of national importance, and should be the subject of imperial care.

The basis of all calculations of the body of water available for gravitation purposes must of necessity be an accurate record over numerous localities of the amount of rainfall, and it is a matter of regret that the work carried out by Mr. G. T. Symons is not incorporated with the Meteorological Department of the Government. In 1865 the British Association appointed a Committee to assist Mr. Symons in developing the system of registration; the total number of stations now at work exceed 2,000 , and the correspondence with these observers, the verification of their instruments and codification of their observations necessarily incur a large amount of expenditure. 'The British Association, after many years' support of the work, feeling it their duty rather to initiate than permanently subsidise investigations, have at length discontinued their grant, and the only sources with which this work of national importance to the country can be carried out by $\mathrm{Mr}$. Symons are voluntary subscriptions and the profits on the annual sale of the volume of "British Rainfall." We trust that one result of the Congress may be to place this work on a more permanent and satisfactory basis, and also that the Ordnance or Geological Survey be charged with the gauging of the chief streams of the country, so that data may be furnished for really estimating what amount of rainfall at cnce runs off in impermeable districts, and how much is absorbed in permeable districts, without which all calculations as to probable yield are to a great extent hypothetical.

It is the fashion in some quarters to abuse the Local Government Board, but when it is realised that they have no authority given them by legislation to survey the country, seek out abuses, suggest and compel improvements,-until they are called to inspect often by the authorities who have allowed abuses to devastate a particular district,-we think that those who read their annual report of work will give them the greatest credit for the industry and ability with which, often at much personal discomfort, they track not only the fever-germs to their source, but confront the ignoranc and obstinacy of the small local authorities. We hoepe that the action of the Society of Arts, in bringing these matters prominently before the country may lead to the scope of the Local Government Board being so enlarged, their staff increased, and their sources of information widened, that they may become a Department of Health, ever ready not merely to find out the cause of disease, but to prevent the possibility of its occurrence. Towards this end, in rousing public opinion to the exigencies of the question, these congresses cannot be, perhaps, too highly valued. Already out of the congress held this year, a National Water Supply Exhibition has been inaugurated at the Royal Aquarium, which cannot but tend to popularise the subject, and if it should be possible to find the Exhibition a permanent home, at the South Kensington Museum, it would add an important factor to the already high educational value of that institution. Should a wider knowledge of these subjects become general, and the government legislate in the direction suggested by the Society, it will be felt that its President, the Prince of Wales, in first bringing the subject prominently before the Society, and in lately placing it before the Premier, will have been instrumental in bringing about the once almost Utopian hope of Charles Dickens, in his preface to the Pickwick Papers, that the time will come when " a. few petty boards and bodies-less than drops in the great ocean of humanity which roars around them--are not for ever to loose fever and consumption on God's creatures, at their will, or always to keep their jobbing little fiddles going for a Dance of Death."

\section{THE AUDIOMETER}

A LREADY have experiments of the greatest practical value been made with the wonderful invention of Prof. Hughes described in our last number. Dr. B. W. Richardson has been applying it in two ways: as an Audiometer for the measurement of hearing, and a Sphygmophone for measuring the pulse. Both applications were described at the last meeting of the Royal Society.

The audiometer, as it had been tused, was shown to the Society. It consists of two Leclanchés cells for the battery, a new and simple microphonic key connected with the cells and with two fixed primary coils, and a secondary or induction coil, the terminals of which are attached to a telephone. The induction coil moves on a bar between the two fixed coils, and the bar is graduated into 200 parts, by which the readings of sound are taken. The graduated scale is divided into 20 centims., and each of these parts is subdivided into 10 , so that the hearing may be tested from the maximum of 200 units to $0^{\circ}-$ zero. The fixed coil on the right hand contains 6 metres of wire; the fixed coil on the left hand contains roo metres. By this means a long scale from the left hand coil is produced. The secondary coil contains 100 metres of wire.

In using the instrument, the induction coil is moved. along the scale from or towards the larger primary, as may be required, and the degrees or units of sound are read from the figures on the scale, the sound being made by the movement of the microphonic key between the battery and the primary coils.

The instrument may be considered to afford the most satisfactory means for testing the hearing power of all persons who can define a sound. The range of sound is sufficient at the maximum-200-for every one who is not absolutely deaf ; $0^{\circ}$, or zero, is a point of positive silence from the instrument, or rather from the sound. which it produces through the telephone.

One of the first facts learned with the audiometer is the suddenness with which the sound is lost to those who are listening. The sound is abruptly lost within a range of $2^{\circ}$; that is, within one-hundredth part of the entire scale. This is the case with those who are very deaf as well as with those who hear readily. 